\title{
Developing Chemistry Students' Study Skills through Integration of Visual Organizers in Teaching ESP
}

\author{
Anastasia Sitnikova \\ Surgut State University \\ Correspondence concerning this article should be addressed to Anastasia Sitnikova, Department of \\ Foreign Languages, Surgut State University, 1 Lenin Ave., Surgut, Russian Federation, 628412. \\ E-mail: simonova_a@inbox.ru
}

Olga Simonova

Surgut State University

Correspondence concerning this article should be addressed to Olga Simonova, Department of English Language Teaching Methods and Translation, Surgut State University, 1 Lenin Ave., Surgut, Russian Federation, 628412.E-mail: soa27@mail.ru

Mrityunjoy Kar

Free University of Berlin

Correspondence concerning this article should be addressed to Dr. Mrityunjoy Kar, Institute of Chemistry and Biochemistry, Free University of Berlin, 3 Takustrasse, Berlin, Germany, 14195.

E-mail: mkar@zedat.fu-berlin.de

This study is aimed at development chemistry students' study skills through integration of visual organizers (VOs) in teaching English for Special Purposes (ESP). The research specifically examined the students' attitude toward the chemistry content of English classes and the achievement of two groups of 54 students under study. The results of the study indicated that there is a significant difference between the level of study skills in dealing with chemistry in English of the students in the experimental group before and after the experiment. The result of students' perception about visual organizers, as a strategy and approach to teaching English through chemistry, highlighted the rationale in this undertaking. All communicative activities and presentations used by the teacher in the class incorporating visual organizers in identified formats such word webbing, web diagram, flowcharts, concept maps, Venn diagram and pictorial graphics obtained a positive perception of chemistry information in English. Performance, on the other hand, indicated the VO's effectiveness in facilitating the learning of English and study skills development. This analysis implied that the experimental group performed significantly better than their peers in the control group. Facilitating English learning through chemistry content can be made through integrating visual organizers that help develop students' study skills. Hence, the use of visual organizers effect changes in learning chemistry content for the better. Visual organizers help students perform better and improve their attitude toward learning English for professional communication.

Keywords: competence, skills, study skills, visual learning, visual organizers, facilitating learning, attitude toward English trough chemistry, student performance

The implementation of the Federal State Educational Standards of Higher Professional Education in Russian universities, as one of the most significant impacts of the Bologna Process, has influenced competence-oriented teaching involving students' acquisition of professional knowledge 
and skills. Among the key European competences for lifelong learning two are under the study here: communication in a foreign language and learning to learn. When studying and researching chemistry students are supposed to develop their cognitive competence including study skills or strategies and a communicative competence based on foreign language knowledge within a professional context. Cognitive competence as a component of learner centered educational paradigm (Khutorskoy, 2003) is the system of general educational skills representing ways of receiving and using knowledge that are universal for many educational disciplines (p. 58). Communicative competence as the goal for language education is 'composed of grammatical, sociolinguistic and strategic competences' (Canale, Swain, 1980, p. 27).

The effectiveness of students' performance in university is determined by their ability to study efficiently. The results of having poor study skills are low grades, frustration or wasted time. No two people study the same way and have the same learning style. However, there are some general teaching and learning techniques that help students achieve good results. The aim of the present research was to develop study skills of students learning chemistry through the integration of visual organizers (VOs) in teaching English for Special Purposes. Teaching English to chemistry science students during their first university year is supposed to involve them in the scientific aspects of the target study area - chemistry through reading texts loaded with professional terms and science vocabulary in English. Although some study skills are taught at school, first-year students have numerous problems to cope with during their learning, for example, reading texts on chemistry and extracting information from them, acquiring new terminology and applying it in oral and written communication, etc.

\section{Materials and Methods}

The study's theoretical background is based on two educational paradigms: the personality-oriented and the competence approaches. The personality-oriented paradigm defined by A. V. Khutorskoy as, "the set of the intercorrected semantic orientations, knowledge, abilities, skills and experience of pupil's activity, that is necessary for the realization of personality and socially significant productive activity in relation to a certain circle of the object of reality" (p. 143).

Another important paradigm, called "the competence paradigm", influences all stages of the educational system especially in vocational education. A competence 'means the ability to apply knowledge know-how and skills in a stable/recurring or changing situation' (Gordon, et al., 2009)). Competences described by I. A. Zimnyaya (2003) as, "some internal, potential, hidden psychological new formations: knowledge, notions, program (algorithms) of actions, systems of values and relations which then are reflected in a man's competences" (p. 8), in fact include abilities or set of skills possessed by a person. It is obvious that the two terms 'competence' and 'skills' are interconnected. According to the CASE network report, a skill is defined as 'the ability, usually learned, and acquired through training to perform actions that achieve a desired outcome' (Gordon et al., 2009, p. 26). The term 'skill' is used (Winterton, Stringfellow, 2005) to refer to a level of performance, in the sense of accuracy and speed in performing particular tasks (p. 10). Proctor and Dutta (1995) define a skill as 'goaldirected, well-organized behavior that is required through practice and performed with economy of effort' (p. 18). Among numerous kinds of skills (labour, social, life, etc.) study skills are considered as those ones acquired through learning or experiences.

The problem of forming study skills has been actively researched by Currie (2005), Kennedy (2005), Drew and Bingham (2010), Cottrell (2013). Considering study skills or study strategies as the approaches essential for lifelong learning, Stella Cottrell (2013) claims that study skills might be developed only at the university level. In 'The Study Skills Handbook' she notes that 'study skills evolve and mature though practice, reflection, trial and error, and feedback from others...' (p. 10). All the researchers note that study skills help students deal with the process of organizing and acquiring new information, processing, interpreting or applying it. They are also necessary for effective reading and writing, mind-mapping and note-taking.

Russian didactics have introduced some categories for study skills. For instance, G. K. Selevko (2003) considers five groups of study skills such as: 1) planning skills; 2) learning organization skills; 3) information cognitive skills; 4) thinking skills; 5) performance selfassessment.

According to Babansky's (1990) theory of rational study management, study skills are divided into three groups: 1) study-organizational skills which help to set up and apply the objectives of work, plan the activity rationally and create efficient working conditions; 2) study-informative skills, for example, extracting information from books, do some observations; 3) study-intellectual skills, for example, the ability to self-motivate a student's activity, such as an attentive perception of information, rational memorizing and logic conceptualization of study materials, selfassessment of cognitive activities. This classification is used in the present study as the basis for working out the students' progress evaluation criteria. 
Students' study skills development is provided by a range of curriculum subject areas, including a foreign language. Knowledge of another language that helps students develop skills to share ideas about science, for example chemistry, in their professional communication with people from other countries is rather important in our global technological society. Overton Johnson and Scott (2011) note that chemisty students' study and communication skills help them fulfill their true potential during their studies, and to enhance their employability beyond university. Language learning at university level is contextualized and supported by various resources such as textbooks, additional materials from the Internet, multimedia and visual (graphic) organizers.

The second key term of the present study is 'visual organizers' (VOs) that are drawings or formats used to represent information and to show relationships between ideas, for example, tables, graphs, charts, timelines, diagrams, flowcharts, etc. The purpose of using visual organizers is to help students think more critically and at higher levels of cognition than if they only focused on reading a text and taking notes. Visual organizers also help to process the information at higher levels of comprehension, analysis, synthesis, application, and evaluation.

Some research (Arnheim, 1969; Silverman, 2005; Mayer \& Massa, 2003) consider visualizing as one of the main ways of learning. As Arnheim wrote: "The clarification of visual forms and their organization in integrated patterns as well as the attribution of such forms to suitable objects is one of the most effective training grounds of the young mind". The research by Linda K. Silverman (2005) suggests that less than $30 \%$ of the population strongly uses visual/ spatial thinking, another $45 \%$ uses both visual/spatial thinking and thinking in the form of words, and 25\% thinks exclusively in words. So, visualizing in the form of drawings, pictures, diagrams or charts help learners understand more complex information. Moreover, as Mayer and Massa (2003) claim 'People with high spatial ability have higher proficiency in creating, holding and manipulating special representations' $(\mathrm{p}$. 838).

In the academic context the term 'graphic organizers' is used more often than visual organizer (VOs), so we may consider them as synonyms. According to G. Dye (2000) 'graphic organizers are visual displays that make information easier to understand' (pp. 72-76). Hall and trangman (2002) noted that integrating graphic organizers can be supportive of teacher's teaching and student learning. It provides holistic representation of facts and concepts and their relationships within an organized frame.

\section{Peculiarities of Teaching ESP to Chemistry}

\section{Students}

Teaching English to students studying chemistry as their major is challenging and has some specific features for both teachers and students because they need to know the content-obligatory language, i.e. the vocabulary, grammatical structures and functional language for communication in this subject. As our teaching ESP experience shows that the first-year students have a necessary level of their language competence (between $\mathrm{A} 2$ and $\mathrm{B} 1$ ) and they know the content-compatible language, i.e. how to use grammatical structures to describe a process, cause and effect as well as general vocabulary, for example, the names of some chemical elements "oxygen", "hydrogen", etc. By the end of the course the students are supposed to know subject-specific language to be able to communicate in the professional context.

Our study has been influenced by the fact that the students in their first university year might face two challenging things: studying chemistry as a difficult 'abstract' science, on the one hand, and the English language that might create misconceptions as far as students' processing of content is concerned, on the other hand.

\section{Research Questions and Hypothesis}

The study is intended to facilitate students' study skills with the help of visual organizers' integration in English language teaching to chemistry students. Specifically, our study attempted to answer the following problems:

1. Is there a significant difference in study skills of chemistry science students in (a) the experimental group exposed to using VOs and (b) the control group exposed to the traditional English language teaching method before and after intervention?

2. What is the perception of chemistry students exposed to lessons integrating graphic organizers in learning English for specific purposes?

3. How does the achievement test in reading the text on chemistry done by the students in the experimental group differ from those ones from the control group?

Before the research we had put forward the following hypothesis: by comparing or contrasting information, identifying cause or effect relationships, classifying vocabulary and information the chemistry students will develop their study skills while using visual organizers (mind-mapping, tables, graphs, charts, diagrams, flowcharts) in learning English with chemical content and improve their study skills and content-obligatory language level. 


\section{Methods}

The study was conducted with two groups of the first-year students (52 participants) at the Institute of Natural Sciences (Surgut State University, Russia) involved in the research work as the experimental and control groups. Admission test result on chemistry and on-line Cambridge English test of these students were used as basis for the selection to heterogeneous.

The research methodology consists of a reference analysis, a quantitative analysis of the results of the survey, language testing, and an achievement test on reading a chemistry text.

The framework of the study includes three stages: the first stage, a theoretical and pre-experimental, took place in 2012-2013 academic year. Its main aim is defining the theoretical basis for the research including the selection of the participants, tools and methods of study. The second (experimental) stage was in the 2013-2014 academic year. It was aimed at integration of visual organizers in teaching an English language course to chemistry students. During the final stage of the study in 2015 all data and results were analyzed and described. The stages, their aims and methods of study are presented in Table 1.

Table 1

The stages of the research work

\begin{tabular}{|c|c|c|c|}
\hline & Stage & Aims & Methods of study \\
\hline & $\begin{array}{l}\text { Theoretical and } \\
\text { pre-experimen- } \\
\text { tal stage (2012- } \\
2013 \text { academic } \\
\text { year). }\end{array}$ & $\begin{array}{l}\text { To define the } \\
\text { theoretical and } \\
\text { methodological } \\
\text { basis for the re- } \\
\text { search including } \\
\text { the selection of } \\
\text { the participants, } \\
\text { tools and meth- } \\
\text { ods of study. }\end{array}$ & $\begin{array}{l}\text { Reference analysis; } \\
\text { Language testing; } \\
\text { Selection of } \\
\text { students; } \\
\text { Preparing study } \\
\text { texts and visual } \\
\text { organizers }\end{array}$ \\
\hline I. & $\begin{array}{l}\text { Experimental } \\
\text { stage (2013- } \\
2014 \text { academic } \\
\text { year). }\end{array}$ & $\begin{array}{l}\text { To integrate } \\
\text { visual organiz- } \\
\text { ers in teaching } \\
\text { English language } \\
\text { course to chem- } \\
\text { istry students }\end{array}$ & $\begin{array}{l}\text { Practical method } \\
\text { (integration VOs in } \\
\text { teaching ESP); } \\
\text { Descriptive } \\
\text { method } \\
\text { Assessment } \\
\text { method }\end{array}$ \\
\hline II. & $\begin{array}{l}\text { Final stage } \\
(2015)\end{array}$ & $\begin{array}{l}\text { To analyze the } \\
\text { results of the } \\
\text { study. }\end{array}$ & $\begin{array}{l}\text { Assessment } \\
\text { method } \\
\text { Reflexive method }\end{array}$ \\
\hline
\end{tabular}

\section{Research Procedure}

In the first stage of the study the studentsparticipants from the experimental and control groups had an on-line language test (www.camridgeenglish. org/test- your-english). Their results of the entrance exam on chemistry were also taken into consideration. As shown in Table 2, the English language testing and the students' performance in state chemistry exams have the insignificant $t$-value which is at the 0.05 level, that means that the two groups (EG and CG) are almost equal in the experimental work.
The teaching resources for the study include the basic course books for teaching chemistry in English to students at SurSU, "The World of Chemistry" by M. M. Kutepova (2005) and "About the Foundations of Chemistry. A Practical Course of English for the First Year Chemistry Students" by N. A. Stepanova (2011). Moreover, the materials from the specialized blog for chemical science students "Chemistry English" (http://esp-chemistry.blogspot.ru/) were widely used during the study.

The main purpose of the experimental stage of the study was to facilitate students' learning environment to develop their study skills by means of integrating various visual organizers in the English language class in the experimental group. Teaching English in the control group was based on the traditional approach aimed at learning grammar and vocabulary, reading texts on chemistry issues, writing abstracts and annotations to the articles. While teaching reading in the CG we used skim reading for gist, so students had to read and find the answers to questions or translate the text. Whereas in the EG the students brainstormed the main idea of the text based on some key words or a title, they used mind-mapping techniques to represent the content of the text. Different types of reading were used, including scanning, skimming or reading for detailed comprehension with the students in the EG having to transfer information in the form of diagrams or charts. While teaching writing the students of the CG were asked to translate new words or give their definitions. In both groups the students were taught how to write abstracts and to take notes. Communicative listening and speaking skills in the CG were taught through answering questions or True/ False statements activities, whereas the students in the EG were involved in graphic presentation of the information, describing the graphs or process cycle, making reports with Power Point Presentation. The different methods and teaching techniques used the CG and EG groups of chemistry students are presented in Table 3.

\section{Levels of Study Skills' Development}

One of the instruments for data collection was selfassessment on the basis of the criteria and descriptors worked out to compare the levels of study skills' formation in English language chemistry according to the Common European Framework of Reference, "The Can-do-statements" and Babansky's classification of study skills. Table 4 represents the criteria for selfevaluation of the level of study skills' development in the chemistry content-obligatory English language course with integration of VOs. In the first stage of the study the students and teachers from both groups assessed their study skills on the basis of the suggested descriptors. After the experimental English teaching 
Table 2

Students' English test and Chemistry exam results

\begin{tabular}{lcccccc}
\hline & $\begin{array}{c}\text { English test (aver- } \\
\text { age score from 15) }\end{array}$ & $\begin{array}{c}\text { Mean } \\
\text { difference }\end{array}$ & p-value & $\begin{array}{c}\text { State chemistry } \\
\text { exam scores }\end{array}$ & $\begin{array}{c}\text { Mean } \\
\text { difference }\end{array}$ & p-value \\
\hline Experimental group (EG) & 17 & 1 & Less 0,05 & 84 & & \\
Control group(CG) & 16 & & & 85 & 1 & Less 0,05 \\
\hline
\end{tabular}

Table 3

Teaching methods and techniques in Control and Experimental Groups

\begin{tabular}{|c|c|c|}
\hline Communicative skills & Control group & Experimental group \\
\hline Reading & $\begin{array}{ll}- & \text { reading for gist } \\
-\quad & \text { answering questions } \\
-\quad & \text { translation of the text. }\end{array}$ & $\begin{array}{ll}\text { - } & \text { brainstorming; } \\
\text { - } & \text { mind-mapping the content of the text; } \\
\text { - } & \text { reading for detailed comprehension } \\
\text { - } & \text { information transfer (graphs) }\end{array}$ \\
\hline Writing & $\begin{array}{ll}- & \text { translation of new words } \\
- & \text { definitions } \\
- & \text { written vocabulary exercises } \\
- & \text { writing abstracts } \\
\text { - } & \text { taking notes }\end{array}$ & $\begin{array}{ll}\text { - } & \text { word webbing } \\
\text { - } & \text { concept maps } \\
- & \text { writing project works } \\
- & \text { summarizing } \\
\text { - } & \text { taking notes }\end{array}$ \\
\hline Listening & $\begin{array}{ll}\text { - } & \text { listening for specific information and } \\
\text { skimming; } \\
\text { - } \quad \text { answering questions or True/False } \\
\text { statements }\end{array}$ & $\begin{array}{l}\text { - listening for specific information, skimming } \\
\text { and detailed comprehension with graphic } \\
\text { presentation of the information }\end{array}$ \\
\hline Speaking & $\begin{array}{ll}\text { - } & \text { asking and answering questions } \\
\text { - } & \text { describing the process } \\
\text { - } & \text { short reports }\end{array}$ & $\begin{array}{ll}\text { - } & \text { describing the graphs or process cycle } \\
\text { - } & \text { reports with Power Point Presentation }\end{array}$ \\
\hline
\end{tabular}

Table 4

Levels of study skills' development in the chemistry content-obligatory English language course with integration VOs Low level (equal to A2) Middle level (B1) High level (B2)

\begin{tabular}{|c|c|c|c|}
\hline $\begin{array}{l}\text { Study-organizational } \\
\text { skills }\end{array}$ & $\begin{array}{l}\text { Can understand sentences } \\
\text { and frequently used ex- } \\
\text { pressions, read simple texts } \\
\text { related to areas of most im- } \\
\text { mediate relevance (e.g. very } \\
\text { basic personal information, } \\
\text { chemistry terms). }\end{array}$ & $\begin{array}{l}\text { Can understand the main } \\
\text { points of clear standard } \\
\text { input on familiar chem-- } \\
\text { istry matters; organize } \\
\text { independent study of new } \\
\text { vocabulary in a form of } \\
\text { wordweb and mind map }\end{array}$ & $\begin{array}{l}\text { Can understand the main ideas of complex } \\
\text { text on both concrete and abstract topics, } \\
\text { including technical discussions in the field } \\
\text { of chemistry, can organize vocabulary in a } \\
\text { concept map. }\end{array}$ \\
\hline $\begin{array}{l}\text { Study-informative } \\
\text { skills }\end{array}$ & $\begin{array}{l}\text { Can communicate in simple } \\
\text { and routine tasks requiring a } \\
\text { simple and direct exchange of } \\
\text { information on basic chemis- } \\
\text { try matters. }\end{array}$ & $\begin{array}{l}\text { Can deal with most situa- } \\
\text { tions likely to arise whilst } \\
\text { reading or listening to } \\
\text { professional communica- } \\
\text { tion on chemistry issues. }\end{array}$ & $\begin{array}{l}\text { Can interact with a degree of fluency and } \\
\text { spontaneity on chemistry issues that } \\
\text { makes regular interaction in the pro- } \\
\text { fessional context, can make and explain } \\
\text { graphs and diagrams }\end{array}$ \\
\hline $\begin{array}{l}\text { Study-intellectual } \\
\text { skills }\end{array}$ & $\begin{array}{l}\text { Can describe in simple terms } \\
\text { aspects of his/her back- } \\
\text { ground, basic chemistry mat- } \\
\text { ters with help of simple VOs }\end{array}$ & $\begin{array}{l}\text { Can describe experiences } \\
\text { and process, briefly give } \\
\text { reasons and explanations } \\
\text { for professional opinions } \\
\text { and plans using VOs } \\
\text { (charts, diagrams, etc.). }\end{array}$ & $\begin{array}{l}\text { Can produce clear, detailed text on a } \\
\text { chemistry matter, explain a viewpoint on } \\
\text { a topical issue giving the advantages and } \\
\text { disadvantages of various options, repre- } \\
\text { sent them in a form of VOs }\end{array}$ \\
\hline
\end{tabular}

with wide use of visual organizers in the EG, the study skills evaluation was used again.

Levels of study skills' development in the chemistry content-obligatory English language course with integration VOs.

\section{Results}

At the beginning of the study the question was asked to find out if there was a significant difference in the study skills of chemistry students in the experimental group exposed to VOs and the control group exposed to the traditional English language teaching method 
before and after intervention.

Table 5 represents the difference in the development of study skills in both groups (EG and CG). The obvious dynamics can be seen in both groups as the result of the learning process. Nevertheless, the progress in the experimental group is more than in the control group. If we compare the middle level of study skills development, the difference of study-organizational skills in CG is 10 to 15 , i.e. in 1.5 times more, while in EG the difference is 7 to 15 , i.e. 2.1 times more. The difference of study-informative skills in CG is 6 to 12 , i.e. 2 times more; in EG: 2.25. Comparing the dynamics in the development of study-intellectual skills in both groups there is the following difference in the middle level : in CG 9 to18 (twice bigger), in EG 9 to 20 (2.2). Accordingly, the progress in study skills development in the experimental group is higher than in the control group.

Table 5

Absolute figures of progress development of study skills in $E G$ and $C G$

\begin{tabular}{l|l|c|c|c|c}
\hline \multirow{4}{*}{\multicolumn{1}{c|}{ Study skills }} & Levels & \multicolumn{2}{c|}{$\begin{array}{c}\text { Before the } \\
\text { experimental } \\
\text { work }\end{array}$} & \multicolumn{2}{c}{$\begin{array}{c}\text { After the } \\
\text { experimen- } \\
\text { tal work }\end{array}$} \\
\cline { 3 - 6 } & & CG & EG & CG & EG \\
\hline \multirow{3}{*}{$\begin{array}{l}\text { Study-organiza- } \\
\text { tional skills }\end{array}$} & Low & 16 & 19 & 9 & 3 \\
\cline { 2 - 6 } & Middle & 10 & 7 & 15 & 15 \\
\cline { 2 - 6 } & High & - & - & 2 & 8 \\
\hline \multirow{3}{*}{$\begin{array}{l}\text { Study-informative } \\
\text { skills }\end{array}$} & Low & 20 & 18 & 11 & 3 \\
\cline { 2 - 6 } & Middle & 6 & 8 & 12 & 18 \\
\cline { 2 - 6 } & High & - & - & 3 & 5 \\
\hline \multirow{3}{*}{$\begin{array}{l}\text { Study-intellectual } \\
\text { skills }\end{array}$} & Low & 17 & 17 & 6 & 2 \\
\cline { 2 - 6 } & Middle & 9 & 9 & 18 & 20 \\
\cline { 2 - 6 } & High & - & - & 2 & 4 \\
\hline
\end{tabular}

Answering the second question about the perception of chemistry students exposed to lessons integrating graphic organizers in learning English for specific purposes, the data from questionnaire may be used. While self-assessing their study skills, the students of the EG could explain the purpose and profit of using visual organizers for their English and chemistry learning. According to the survey, the EG students found using visual organizers while reading English texts on chemistry issues as an effective tool to memorize a new vocabulary and understand the content.The third question concerned the difference between the students from EG and CG in the reading test performance. It was the optimal way to evaluate the results of the effectiveness of using visual organizers in teaching English to chemistry students. In the first part of the test the students read the text and chose on from the variants (A, B or C). In the second part, they had to make a pie chart on the information of a chemistry process. The results of the test have also helped prove the effectiveness of using visual organizers, which 'make meaning and their learning meaningful' (Ausubel, 1969).

In Table 6 there are the results of the achievement reading test in EG and $C G$, demonstrating that the students in EG performed much better in the test.

Table 6

Achievement test results

\begin{tabular}{lcc}
\hline Correct answers & Experimental group & Control group \\
\hline $85-100 \%$ & 19 & 9 \\
$70-84 \%$ & 6 & 13 \\
$69-54 \%$ & 1 & 4 \\
Less than 50\% & & \\
\hline
\end{tabular}

\section{Discussion}

The integration of visual organizers in the teaching of English to chemistry students revealed its influence on the development of their study skills. The results of our research indicated that there is a significant difference between the level of study skills in dealing with chemistry content in English of the students in the experimental group before and after the experiment. Therefore, some benefits from the use of visual organizers facilitating students' language and study skills might be suggested for scientific discussion.

Firstly, the results of other studies on the use of graphic organizers (Ausubel, 1960; Al-Hinnawi, 2012; Dye, 2000; Hall, Strangman, 2002; Torres, Espaňa, \& Orleans, 2014) proved that students who used the graphic organizer strategy in learning new vocabulary and grammar, reading a text, writing summaries and doing other classroom and autonomous activities outperformed the students in the control groups. Moreover, the study revealed that the students learning English within their professional context showed high motivation in reading authentic information on chemistry and presenting it in various visual forms.

Secondly, all communicative activities and presentations used by the teacher and the students in the English language class incorporating visual organizers in identified formats such word-webbing, web diagram, flowcharts, concept maps, Venn diagram and pictorial graphics had a good reception of chemistry information. The use of visual organizers as educational tools effects change in learning chemistry content for the better. Visual organizers help students perform better and improve their attitude toward learning English for professional communication.

Thirdly, the study aimed at the development of 
students' study skills that are considered as the basic components of cognitive competence (Babansky, 1990; Khutorskoy, 2002; Raven, Stephenson, 2001; Overton, Johnson, \& Scott, 2011). The lack of study skills (study-organizational, study-informative and study-intellectual skills) prevents students from better performance, in fact it is a constant deficiency in the study methods of many high school and college students. Having good study skills help students apply them in different situations, especially in learning a foreign language with specific scientific context.

The study's hypothesis stated that by comparing or contrasting information, identifying cause or effect relationships, classifying vocabulary and information due to the integration of various visual organizers the chemistry students will develop their study while learning English with chemical content and improve their study skills and content-obligatory language level. The results of the study give some evidence to support the hypothesis and make some contribution to improve teaching ESP on the base of visual learning.

\section{Conclusion}

In conclusion, it might be stated that the goal of the study has been achieved, the hypothesis has been supported by the experiment data described above. It has been shown that by comparing or contrasting information, identifying cause or effect relationships, classifying vocabulary and information the chemistry students develop their study skills while using various visual organizers in learning English with chemical content. Moreover, the main impact of using visual organizers is the increase in students' ability to think more critically and at higher levels of cognition than if they only focused on reading the text and taking notes. Visual organizers helped students to process the information at higher levels of comprehension, application, analysis, synthesis, and evaluation. By thinking about and organizing information in this way, chemistry students better understand and recall the information in English on chemistry issues.

\section{References}

Al-Hinnawi, A. (2012). The effect of the graphic oraganizer strategy on university students' English vocabulary building. English Language Teaching, 5(12), 62-69.

ALTE CAN DO project. Articles and Can Do statements produced by the members of ALTE. (n.d.). Retrieved form http://www.alte.org/attachments/files/alte cando.pdf
Arnheim, R. (1969). Visual thinking. Berkeley, CA: University of California Press.

Ausubel, D. P. (1960). The use of advance organizers in the learning and retention of meaningful verbal material. Journal of Educational Psychology, 51, 267272.

Babansky, J. K. (1990). Racional'naja organizacija uchebnoj dejatel'nosti [Rational learning management]. In Selected pedagogical works. Moscow, USSR: Pedagogica.

Busan, T. (1993). The mind map book. Retrieved form http://www.tonybuzan.com/about/mind-mapping/

Canale, M., Swain, M. (1980). Theoretical bases of communicative approaches to second language teaching and testing (PDF). Applied Linguistics, 1, $1-47$.

Dye, G. A. (2000). Graphic organizers to the rescue! Helping students link and remember information. Teaching Exceptional Children, 32(3), 72-76.

Fitts, P. M., Posner, M. I. (1967). Human performance. Belmont, CA: Brooks/Cole.

Gordon, J. et al. (2009). Key competences in Europe: Opening doors for lifelong learners across the school curriculum and teacher education. CASE Network Reports, 87. Retrieved from https://www. econstor.eu/bitstream/10419/87621/1/613705459. pdf

Hall, T., Strangman, N. (2002). Graphic organizers. Wakefield, MA: National Center on Accessing the General Curriculum. Retrieved from http://www. cast.org/publications/ncac/ncac_go.html

Khutorskoy, A. V. (2002). Kljuchevye kompetencii kak komponent lichnostno-orientirovannoj paradigmy obrazovanija [Core competences as a constituent of personality oriented paradigm in education]. In Iu. Dic \& A. Khutorskoy (Eds.), Student of an improving school: Collected scientific proceedings (pp. 135-157). Moscow, Russia: IOSO RAO.

Khutorskoy, A. V. (2003). Kljuchevye kompetencii kak komponent lichnostno-orientirovannogo obrazovanija [Key competences as component of lerner-centered paradigm of education]. Narodnoye Obrazovaniye, 2, 56-65.

Kutepova, M. M. (2001). The world of chemistry: English language course for chemistry science students. Moscow, Russia: University.

Lobanova, N., Skvortsov, V. (Eds.). (2011). Lifelong learning: Continuous education for sustainable development. In Proceedings of international cooperation (Vol. 9). Retrieved from http://lifelongeducation.ru/files/pdf/2011_en.pdf

Matveeva, E. F. (2007). Teorija i metodika obuchenija himii [Theory and methods of teaching chemistry]. Astrakhan, Russia: Publishing House «Astrakhan University».

Overton, T., Johnson, S., \& Scott, J. (2011). Study 
and communication skills for the chemical sciences. Oxford, UK: Oxford University Press.

Proctor, R. W., Dutta, A. (1995). Skill acquisition and human performance. London, UK: Sage.

Raven, J. (2001). Pedagogical testing: Problems, delusions, prospects. Moscow, Russia: Kogito-Centr.

Raven, J., Stephenson, J. (2001). Competence in the learning society. New York, NY: Peter Lang International Academic Publishers.

Rwehumbiza, R. (2013). Understanding examination techniques and effective study strategies. Retrieved from http://lingualeo.com/ru/jungle/studyskills-332566\#/page/1

Selevko, G. K. (2003). Sovremennye obrazovatel'nye tehnologii [Modern educational technologies]. Moscow, Russia: Narodnoye obrazovanie.

Silverman, L. K. (2005). Upside-down brilliance: The visual-spatial learner. Denver, CO: DeLeon.

Stepanova, N. A. (2011). About the foundations of chemistry. A practical course of English for the firstyear chemistry students. St. Petersburg, Russia: Politechnica.

Torres, M. O., Espaňa, R. C. N., \& Orleans, A. V. (2014). Integrating graphic organizers in facilitating learning chemistry. International Journal of Educational Studies, 1(2), 1-8.

Winterton, J., Delamare-Le Deist, F., Stringfellow, E. (2005). Typology of knowledge, skills and competences: Clarification of the concept and prototype. Thessaloniki, Greece: CEDEFOP.

Zimnyaya, I. A. (2003). Kljuchevye kompetencii - novaja paradigma rezul'tata obrazovanija [Core competences - new paradigm of result in education]. Higher Education Today, 5, 34-42. 